American Journal of Applied Sciences 9 (7): 968-973, 2012

ISSN 1546-9239

(C) 2012 Science Publications

\title{
Community Development and its Influence on Community Policing
}

\author{
Abdul Hadi Sulaiman, Jamilah Othman, Hanina Halimatussaadiah Hamsan, \\ Bahaman Abu Samah and Jeffrey Lawrence D'Silva \\ Institute for Social Science Studies, Universiti Putra Malaysia, Malaysia
}

\begin{abstract}
Problem statement: Undeniably communities around the world are facing numerous challenges in the development process and one of it is to ensure a safe community. To achieve this, community policing is deemed important as an important mechanism that will ensure safety and a freecrime society. The main purpose of this study is to seek the interrelationships between the various approaches in community development and how it can be embedded in community policing. Approach: This study used the existing literature and other relevant documents to seek for the implementation of community policing in Malaysia. Results: The outcome of the study showed that community policing is alive in Malaysia and most communities accept the good cooperation between the police and community in reducing crime. Conclusion: This study showed that more efforts need to be taken to further strengthen collaborative ties between the police and the community as it is evident that such collaboration will help to enhance the well-being of society.
\end{abstract}

Key words: Community development, community policing, security, safety

\section{INTRODUCTION}

Scholars tend to define community as a group of people who not only live in a region with fixed boundaries, but also united by similarities in the way of life, beliefs and practices (Hamzah, 2011; Sail, 2011). Similar definition is also presented by Robinson (1996) who sees the community in terms of differences among the entities within the community with relation to ethnicity, religion, sex, education level, age and economics. Since resources are becoming scarce lately, each member of the community is required to interact with each other effectively with the aim of maximising the usage of available resources that would lead toward sustianable community development (D'Silva et al., 2011).

Community development is often associated with the development of education, rural development, rural sociology and sometimes in community education with the aim of improving quality of life and well-being of individuals and communities. Meanwhile, approaches in community development are referred to methods or ways in helping a community (Samah, 2011). It is also often termed as a process of mobilization efforts from various parties, government agencies, private, NonGovernmental Organizations (NGOs) and local residents, to develop a community with the aim to improve and enhance the quality of life among community members (Sail, 2011). In addition, Ploch (1976) looks at community development in terms of active participation of the community members to carry out programs that can improve their quality of life.

It is often prescribed that there are six important elements in community development: firstly is the composition, in which each member of society will feel that they have an identity and community belonging; second, a system of symbols, language and practice their rituals and feast; thirdly, in terms of possessing the same values and norms; fourth, with regards mutual influence on each other; fifth, share the will and commitment to community development and finally sharing the emotional relationship with each member, sharing the same history and experiences and mutual support to each other (Baker et al., 1994).

Community development approach can be seen in a continuum line separated into two basic concepts "directing community" and "facilitating community" (Samah, 2011). The concept of "directing community" is seen as the willingness of the government agencies to develop a holistic community in accordance with ideas, plans and requirements. It emphasizes technical assistance approach or even popular with the name of top-down approach (Samah, 2011). The concept of "facilitating community" refers to several approaches that lead to the willingness of society to make changes together, in an effort to improve the quality and wellbeing with the help and guidance from change agent. 
Community development approach: Community development is often associated with approach or how to make a change to the community or target group to achieve well-being. As highlighted at the introduction, generally there are several popular approaches such as technical assistance approach, self-help approach and partnership approach. Implementation of this approach depends on (a) the resources and development objectives, (b) the level of community involvement and (c) the sharing of 'power and responsibility between the community and interested or not interested stakeholders.

Technical assistance approach: The technical assistance approach is a community development approach that is geared towards the concept of "directing community". Typically, this type of development is sponsored by government agencies or local authorities in developing an area or community with specific need and reasons. The concentration given by this approach is to do community development activities without involving the communities themselves. In the context of technical assistance, development agents play important roles in developing the community in accordance with the requirements and make a change. This philosophy is to work for the community. Samah (2011) describes the assumptions underlying the approach to technical assistance as follows: (a) parties that make a difference are more efficient and capable in determining what is the best for the community; (b) communities affected by the problem or face the challenges of life and depression are not able to identify the best way to act; (c) it is the responsibility of bringing change to influence the community toward the best for them; and (d) community helpless and responsible for improving their living conditions.

In general, this approach has the potential to assist communities to develop at a basic level. The strength of this approach can be seen in (a) produce the optimal output of the desired goals quickly; (b) the community can be ordered as per the needs and goals; (c) related problems can be identified for corrective action; and (d) development plan is consistent with the requirements, goals and ideology at the top.

Meanwhile, a number of weaknesses were identified by Samah (2011) and they are as follows: (a) communities are not free to determine their needs; (b) community participation is limited to only the recipients; (c) a program organized may not be suitable to the needs, wants, community values and beliefs; (d) determining power in the hands of the community is very low and limited; (e) opportunities and community space to test the abilities, skills and talents are less common; and (f) the development of the formation of self-confidence and a few others.

Kayat and Nor (2006) classify community involvement at this stage as manipulative participation, because almost all elements of the development is owned or controlled by the provider without the consent of the development community and some in the name of community development but does not directly involve the community.

Self-help approach: This approach also refers to the concept of "facilitating community". The main theme of this approach is the readiness of the communities to develop and promote local change towards a more meaningful quality of life. Samah (2011) stressed that in this approach, all matters relating to development, progress and change in communities is discussed, decided and implemented by the communities themselves. Unlike the technical assistance approach, agents of change within the context of this approach serves as a facilitator in identifying problems or needs, develop plans, strategies, action plans, monitoring and regulatory communities together. Among the assumptions of this approach are as follows: (a) community who wish to develop more knowledgeable about the problems and needs; (b) community have their own ability and potential to determine the affairs of their lives; (c) community have the right to decide what they need; (d) the community has the power of determination; (e) opportunity and space should be given to the community to speak and make decisions for their future; and (f) community workers are not experts in determining the community needs.

The strength of this approach lies to the assumptions and philosophy of "working with the community". This philosophy provides plenty of space and opportunity for the community to try and work on their own feet with support from development agencies. In addition, this approach is successful in fostering a sense of ownership and increase the level of a new venture to improve and develop the community. A higher degree of decision on a matter is also a factor in the success and strengths of the community.

However, this approach also has some disadvantages such as if the community is not united, the failure of this approach is extremely high. Sometimes, for every process of development, a lot of time and energy spent on discussion and implementation, for some individuals in the community, it is difficult for them and this will lead to passive participation and withdrawal. In this approach, the influence and power of change agents is difficult to determine, as such, it is difficult to ascertain what has 
helped and guided it to produce an impact on the community.

Partnership approach: Samah (2011) also highlighted the partnership approach. In his view, the approach involves the element of alliance partners, joint venture between the parties that wish to help bring change to the party who wants to help. Parties that wish to help may consist of the government, or the developer. On the other hand, the parties that wants to help, is referred to the community. The role played by the development agencies are as a mediator and facilitator for both parties that the proposed development so that it can be implemented and run smoothly.

The concept of an ideal partner in community development is based on the following assumptions: (a) both sides need each other; (b) both parties cannot reach their goals without the support and assistance of other parties; (c) the partnership or joint venture partners in the relationship fill the needs and goals for the love; (d) collaboration can save time, energy, resources and expertise compared to party work on it and (e) the results or benefits from the joint venture can be beneficial to both parties.

The impact of this partnership approach to practice according to Samah (2011) is that it has several advantages including: (a) use of resources (financial, time, human capital) to the optimum, economical and beneficial to both parties; (b) can integrate internal information with external expertise in order to achieve development goals; and (c) lack of a party can be accommodated by the other party to make a difference.

However, Samah (2011) explained that this approach also has some disadvantages in terms of practice. Views, character and personality of partners is very subjective. The main failure of this approach is more akin to the question of trust, integrity and attitude of both parties involved. If there is a suspicion, the concerned parties may lose confidence and hence this cooperation will disintegrate while defeating the ends of development.

Community policing and community development: Based on the existing literature, the establishment of community policing has a number of objectives that need to be attained and among them are (a) to establish a close cooperation between the police and the community, (b) to create opportunities for communities to solve local people's problems in a group, (c) involving the community in addressing the perception of increased crime and addressing community concerns over crime, (d) to establish a structured procedure between police and the community as a smart (smart partnership) and (e) to implant the spirit of coownership rights in the planning and actionable results (Oliver, 2000; Kerley, 2005).

There is a diverse spectrum of community development making it a vast field of development. Samah (2011) explained that community development can be measured using indicators in the model of quality of life elements that include social, economic, political, educational, safety and security with the ultimate aim is to bring harmony to human. In the context of security, peace of individuals, families, communities and government are the main agenda in determining a country's political stability. Samah (2011) also explained that community development can be categorized in two forms, that is, firstly it be seen as a goal and next it can be viewed as a process. Community development is seen in the perspective as the goal is through the services or actions that leads to the aim of community well-being. The development as a process is referred to as the willingness to take initiative for community initiative and act for change. In the context of community policing, it is believed that community development can be seen as a process to contain and prevent crime. Towards this end, the culture and mindset of society to change, attitudes, awareness, knowledge and commitment to community also need to be improved so that the joint task of combating crime, especially in residential areas and their neighborhood can be achieved (Oliver, 2000; Stevens, 2001; Kerley, 2005; Morabito, 2010). Thus, active and interactive relationship between police and the community is very important to create a collective spirit of cooperation in determining the assurance of public order and safety.

Theory of community development in accordance with community policing: Based on Habermas (1987) theory of communicative action, it is noted that community participation in community development activities in democracy often lead to active participation in state care. This occurs in situations where public opinion and criticism (based on facts and evidence) to be something that should be taken seriously from all stakeholders in an effort to identify problems, attempted solutions to the extent that the policy change (Habermas, 1987). This mature community network can be viewed as "communicatively integrated" (Friedland, 2001).

Habermas (1987) argues that the communicative action formed is shaped at the seam of system and the "life-world". The system covers the language, culture, macro-economic and political influences that form of housing, employment, race ethnicity and class divisions 
in the community legislation. While the term "lifeworld" was seen as "the transcendental site" where speaker and hearer meet, where hire reciprocally raise claims that their utterances fit the world and where they can criticize and confirm those validity claims, settle their disagreements and arrive at agreements (Habermas, 1987). This theory involves individuals, groups and networks in which their voices are part of the "life-world".

Communicative action theory is practical and effective in driving the development of community expectations. Habermas (1987) mentioned that in general, this theory can help the community to combine with experts from technical knowledge, corporate knowledge, local knowledge and practical knowledge. Combination of this knowledge will lead to new knowledge (emancipatory knowledge) that provides ideas and action plan appropriate and practical. Habermas (1987) also explained that it is an impossible task if the community that wished to practice the principle of full participation to apply this theory as not/is unlikely to happen if only the intercept of knowledge by one party without the other specialties.

While putting this theory into the context of community policing, it was found that there are some basic similarities. Although community policing program is initiated at the government level, but it only can survive with an active involvement of all stakeholders such as the police department, local authorities, non-governmental organizations, expert panel, community leaders, media's and other interested parties in providing feedback and information in a forum or in a discussion table. It is likely that Habermas (1987) theory of communicative action is guided by the intersection of technical and corporate knowledge with local and practical knowledge. Combined, they can lead to a new kind of ideas and action.

\section{MATERIALS AND METHODS}

The nature of this study is exploratory and hence the methodology employed to obtain the data is through a search of the existing literature and the various documents that are available in the natural settings. This would help to the discovery of knowledge in an open and unbiased description of various experiences in the natural settings.

\section{RESULTS}

The results of this study showed that in Malaysia, crime prevention is already enshrined in the role and functions of the police force as stated in the the Police Act 1967, the Prevention and Detection of Crime. It can be implemented either by reactive or proactive action. Reactive action is an action taken after the crime occurred and these include investigation, arrest, prosecution and a special operation to track criminals. While proactive actions were made before a crime was committed (guidelines for implementation of community policing police). The growth of the nation building and human civilization in parallel increase the shape and trend of crime in country and this issue has been pointed out by Sulaiman (2012) who further elaborated that the development, attitudes and situations in the community had given the opportunities and space for criminals to commit crimes. The increase in criminal cases in Malaysia can be seen from the statistical reports since 1997 with an increase from 121,176 cases to 156,455 cases in 2002 and further rose to 198,622 in 2006 (Sulaiman, 2012).

Moreover, it was identified that there are a variety of factors that are associated to generate crime in community. Environmental factors such as type of building, pedestrian space, increased population, polarity of education, advances in ICT, innovation and globalization encourage more crime. Although the police force always play a major role in combating crime, but the challenges faced by the police force is the lacking in the number of personnel in the field compared to the area and the population that need to be monitored.

\section{DISCUSSION}

Recognizing the fact that policing approach can no longer be focused on reactive actions only, a more dynamic concept of prevention must be organized by the Police Force. In 2007, the police had developed a Five-Year Strategic Plan in order to strategize and provide clear direction in dealing with various crisis and the challenges faced. Based on this plan, one of the core elements is the increase in number of crimes and addressing communities concern about crime.

Thus, the concept of community policing was introduced and used as a police philosophy in implementing crime prevention. Community policing requires the police and the community to work together as comrades in identifying effective actions and address the related issues of crime and social ills in their own community. It is a first step to support the community closely to provide assurance about the police presence with them in an effort to prevent crime. This method will provide an opportunity for police officers to interact directly with members of the local community. 
In addition, the holistic approach involves a number of stakeholders such as (a) local authority, (b) government agencies such as Immigration Department, Road Transport Department, Safe Guard Agency and Civil Defense Department, (c) NonGovernmental Organization (NGO's), (d) registered organization, (e) media, (f) politicians and (g) private sector as a catalyst to the process and functionality of community policing in Malaysia.

During the five year (2007-2011) period of implementation community policing, the police had done many things together with the community. Beginning from a series of discussions and meetings, regular patrols, local census, awareness talks, road shows, courses and workshops, sharing of information through social media like Facebook and twitter until the launch of the Community Policing at the national level. All these activities have shown a positive relationship of police and the community in combating and reporting crime at the community level, while reducing public fear of crime.

After five years of implementation of community policing in Malaysia, most communities accept the concept of good police cooperation and community in reducing crime. Some of the evidences of communities that received community policing programs such as in Puchong and Serdang of Selangor have shown the effect of reducing the crime rate and increase the knowledge, skills, attitudes and aspirations of the residents of crime prevention activities, report information on crime and also save the property before crime. Besides, it also formed a good relationship between the police and community members to facilitate the development process through a series of discussions with residents, complaints and activities with the local community.

\section{CONCLUSION}

The increase of crime and crime related reports since 1997 had reduced the confidence of society and social institutions in Malaysia to the credibility of the police force. Coupled with the uncertain political stability, has led the public to no longer feel safe to go out sightseeing or outdoor activities. They are concerned about their personal safety and property from criminals. This phenomenon has indirectly changed the landscape quality of life and led to low levels of human wellbeing. As such, the Malaysian government through its relevant agencies, NGOs and stakeholders in crime and security issues has worked very hard to identify the root cause of the problem, formulate and implement initiatives to ensure the smooth running of this country.
One of these initiatives is that the police have taken prudent steps to involve community participation in problem-solving partnerships with public safety. The implementation of community policing has led to active participation of the community to play a role in reducing crime in their neighborhood. Various community programs were organized by the police and the residents' committee to provide knowledge, understanding and skills in handling case related crimes. The impact of community policing has enhanced the ability of communities in preventing crime, making communities to be more confident and increase the well-being of the society as a whole.

\section{REFERENCES}

Baker, E.A., B.A. Israel and S.J. Schurman, 1994. A participatory approach to worksite health promotion. J. Amb. C. Manage., 17: 68-81. PMID: 10133290

D'Silva, J.L., B.A. Samah, H.A.M. Shaffril and N. Man, 2011. Preservation of the enviornment through sustainable agriculture practices: A case study on the attitude of crop farmers. Am. J. Environ. $\quad$ Sci., 7 : 195-199. DOI: 10.3844/ajessp.2011.195.199

Friedland, L.W., 2001. Communication, community and democracy: Toward a theory of the communicatively integrated community. Commun. Res., 28 : 358-391. DOI: $10.1177 / 009365001028004002$

Habermas, J., 1987. The Theory of Communicative Action: Lifeworld and System: A Critique of Functionalist Reason. 1st Edn., Beacon Press, Boston, MA.

Hamzah, A., 2011. An Evaluation on Community Development Programme: Strategy for Effective Communication Management. In: Community Development to Built Potential and Community Empowerment (Pembangunan Komuniti Membina Keupayaan and Potensi Masyarakat), Alavi, K., R.M. Sail and N.A. Kamarudin (Eds.). UPM Press, Serdang, Selangor.

Kayat, K. and N.M. Nor, 2006. Community involvement in community development programme: A study on homestay programme in Kedah. Akademika, 67: 77-102.

Kerley, K.R., 2005. Policing and Program Evaluation. 1st Edn., Pearson/Prentice Hall, Upper Saddle River, N.J., ISBN-10: 0130394734, 162.

Morabito, M.S., 2010. Understanding community policing as an innovation: Patterns of adoption. Crime Delinquency, 56: 564-587. DOI: 10.1177/0011128707311643 
Oliver, W.M., 2000. The third generation of community policing: Moving through innovation, diffusion and institutionalization. Police Q., 3: 367-388. DOI: $10.1177 / 109861110000300402$

Ploch, L., 1976. Community development in action: A case study. J. Commun. Dev. Soc., 7: 5-16.

Robinson, T., 1996. Inner-city innovator: The nonprofit community development corporation. Urban Stud., 33: 1647-1670. DOI: $10.1080 / 0042098966547$

Sail, R.M., 2011. Approaches in Community Development in Multiethnic Group. In: Community Development to Built Potential and Community Empowerment (Pembangunan Komuniti Membina Keupayaan and Potensi Masyarakat), Alavi, K., R.M. Sail and N.A. Kamarudin (Eds.). UPM Press, Serdang, Selangor.
Samah, A.A., 2011. Theory an Practice on Community Development in Wellfare services. In: Community Developement to Built Potential and Community Empowerment (Pembangunan Komuniti Membina Keupayaan and Potensi Masyarakat). Alavi, K., R.M. Sail and N.A. Kamarudin (Eds.). UPM Press, Serdang, Selangor.

Stevens, D.J., 2001. Community policing and managerial techniques: Total quality management techniques. Police J., 74: 26-41.

Sulaiman, S., 2012. Evaluation of rakan cop programme in Kuala Lumpur. MS.c Thesis, Universiti Putra Malaysia, Serdang. 